\title{
The oxygen isotope composition of phosphate released from phytic acid by the activity of wheat and Aspergillus niger phytase
}

\author{
C. von Sperber ${ }^{1,2}$, F. Tamburini ${ }^{1}$, B. Brunner ${ }^{3}$, S. M. Bernasconi ${ }^{4}$, and E. Frossard ${ }^{1}$ \\ ${ }^{1}$ Institute of Agricultural Sciences, ETH Zurich, Eschikon 33, 8315 Lindau, Switzerland \\ ${ }^{2}$ Department of Biology, Stanford University, 473 Via Ortega, Y2E2 Building, Stanford, CA 94305-5020, USA \\ ${ }^{3}$ Department of Geosciences, University of Texas at El Paso, 500 W. University Ave, El Paso, TX 79902, USA \\ ${ }^{4}$ Geological Institute, ETH Zurich, Sonnegstrasse 5, 8092 Zurich, Switzerland \\ Correspondence to: C. von Sperber (csperber@stanford.edu)
}

Received: 28 February 2015 - Published in Biogeosciences Discuss.: 30 March 2015

Revised: 27 May 2015 - Accepted: 08 June 2015 - Published: 14 July 2015

\begin{abstract}
Phosphorus (P) is an essential nutrient for living organisms. Under P-limiting conditions plants and microorganisms can exude extracellular phosphatases that release inorganic phosphate $\left(\mathrm{P}_{\mathrm{i}}\right)$ from organic phosphorus compounds $\left(\mathrm{P}_{\text {org }}\right.$ ). Phytic acid (myo-inositol hexakisphosphate, $\mathrm{IP}_{6}$ ) is an important form of $\mathrm{P}_{\text {org }}$ in many soils. The enzymatic hydrolysis of $\mathrm{IP}_{6}$ by phytase yields available $\mathrm{P}_{\mathrm{i}}$ and less phosphorylated inositol derivates as products. The hydrolysis of organic $\mathrm{P}$ compounds by phosphatases leaves an isotopic imprint on the oxygen isotope composition $\left(\delta^{18} \mathrm{O}\right)$ of released $\mathrm{P}_{\mathrm{i}}$, which might be used to trace $\mathrm{P}$ in the environment. This study aims at determining the effect of phytase on the oxygen isotope composition of released $\mathrm{P}_{\mathrm{i}}$. For this purpose, enzymatic assays with histidine acid phytases from wheat and Aspergillus niger were prepared using $\mathrm{IP}_{6}$, adenosine $5^{\prime}$-monophosphate (AMP) and glycerophosphate $\left(\mathrm{GPO}_{4}\right)$ as substrates. For a comparison to the $\delta^{18} \mathrm{O}$ of $\mathrm{P}_{\mathrm{i}}$ released by other extracellular enzymes, enzymatic assays with acid phosphatases from potato and wheat germ with $\mathrm{IP}_{6}$ as a substrate were prepared. During the hydrolysis of $\mathrm{IP}_{6}$ by phytase, four of the six $\mathrm{P}_{\mathrm{i}}$ were released, and one oxygen atom from water was incorporated into each $P_{i}$. This incorporation of oxygen from water into $P_{i}$ was subject to an apparent inverse isotopic fractionation $(\varepsilon \sim 6$ to $10 \%$ ), which was similar to that imparted by acid phosphatase from potato during the hydrolysis of $\mathrm{IP}_{6}$ $\left(\varepsilon \sim 7 \%\right.$ ), where less than three $\mathrm{P}_{\mathrm{i}}$ were released. The incorporation of oxygen from water into $\mathrm{P}_{\mathrm{i}}$ during the hydrolysis of AMP and $\mathrm{GPO}_{4}$ by phytase yielded a normal isotopic fractionation $(\varepsilon \sim-12 \%)$, similar to values reported for acid phosphatases from potato and wheat germ. We at-
\end{abstract}

tribute this similarity in $\varepsilon$ to the same amino acid sequence motif (RHGXRXP) at the active site of these enzymes, which leads to similar reaction mechanisms. We suggest that the striking substrate dependency of the isotopic fractionation could be attributed to a difference in the $\delta^{18} \mathrm{O}$ values of the $\mathrm{C}-\mathrm{O}-\mathrm{P}$ bridging and non-bridging oxygen atoms in organic phosphate compounds.

\section{Introduction}

myo-Inositol hexakisphosphate (phytic acid, $\mathrm{IP}_{6}$ ) is a very important storage molecule for $\mathrm{P}, \mathrm{Mg}, \mathrm{K}, \mathrm{Fe}$ and $\mathrm{Zn}$ located in plant seeds (Cosgrove and Irving, 1980; Raboy, 1997; Shears and Turner, 2007). It is crucial for seedling growth. Lott et al. (2000) estimated the yearly global production of $\mathrm{IP}_{6}$ in seeds and fruits to be close to $3.5 \times 10^{7} \mathrm{t}$, containing $9.9 \times 10^{6} \mathrm{t}$ of P. Plant residues introduce $\mathrm{IP}_{6}$ to soil. There it can be stabilized on particles by sorption mechanisms $(\mathrm{Og}$ nalaga et al., 1994) and can comprise up to $50 \%$ of organic phosphorus (Dalal, 1977; Anderson, 1988), becoming in some instances the dominant form of organic phosphorus (Turner, 2007). In other cases, however, $\mathrm{IP}_{6}$ can be rapidly mineralized after its introduction in a soil (Doolette et al., 2010).

Plants and soil microorganisms take up phosphorus $(\mathrm{P})$ as inorganic phosphate $\left(\mathrm{P}_{\mathrm{i}}\right)$ from the soil solution and low $\mathrm{P}_{\mathrm{i}}$ concentrations can limit biological growth and crop production in many ecosystems (Ehlers et al., 2010; Richardson et al., 2011). Under P-limiting conditions, some plants and mi- 
croorganisms can exude phytases, which catalyze the hydrolysis of phosphomonoester bonds in $\mathrm{IP}_{6}$ leading to the release of inorganic phosphate $\left(\mathrm{P}_{\mathrm{i}}\right)$ (Hayes et al., 1999; Richardson et al., 2000, 2001; Lung and Lim, 2006; Li et al., 1997a, b). The exudation of phytases might therefore be an important mechanism of plants and microorganisms to utilize a fraction of soil organic phosphorus. For example, Zimmermann et al. (2003) showed that a transgenic potato expressing a synthetic gene encoding for phytase was able to take up a significant amount of $\mathrm{P}$ from $\mathrm{IP}_{6}$, whereas the potato wild type was not. However, the cycling and bioavailability of $\mathrm{IP}_{6}$ and the role of phytase in terrestrial ecosystems are still poorly understood (Turner et al., 2000, 2002).

The oxygen isotopes associated with phosphorus might be used to trace these enzymatic processes and to shed new light on the cycling and bioavailability of $\mathrm{IP}_{6}$ in soils (Frossard et al., 2011). In the terrestrial environment, the oxygen isotope composition $\left(\delta^{18} \mathrm{O}\right)$ of phosphate has been used as a tracer in the terrestrial environment to study the cycling of $\mathrm{P}$ in soils (Zohar et al., 2010a and b; Tamburini et al., 2010, 2012; Angert et al., 2011, 2012; Gross and Angert, 2015), in plants (Young et al., 2009; Pfahler et al., 2013) and in aerosols (Gross et al., 2013). Under ambient conditions and in the absence of biological activity, the $\delta^{18} \mathrm{O}$ of phosphate does not change (Kolodny et al., 1983; O'Neil et al., 2003). However, biological uptake of phosphate leads to a substantial alteration of $\delta^{18} \mathrm{O}$ values (Paytan et al., 2002; Blake et al., 2005; Stout et al., 2014). This alteration is due to the activity of intracellular pyrophosphatases, which catalyze a complete oxygen exchange between $\mathrm{P}_{\mathrm{i}}$ and water, leading to an equilibrium isotope fractionation (Cohn, 1958; Longinelli and Nuti, 1973; Blake et al., 2005; Chang and Blake, 2015). Furthermore, the hydrolysis of organic $\mathrm{P}$ compounds by extracellular phosphomonoesterases and phosphodiesterases leads to the incorporation of one or two oxygen atoms from water into released $\mathrm{P}_{\mathrm{i}}$ (Cohn, 1949; Liang and Blake, 2006, 2009; von Sperber et al., 2014). This incorporation of oxygen from water is subject to a kinetic isotope fractionation $(\varepsilon)$, which has been determined for alkaline phosphatases (Liang and Blake, 2006), phosphodiesterases and nucleotidases (Liang and Blake, 2009), and acid phosphatases (von Sperber et al., 2014). To date, the effect of phytases on the $\delta^{18} \mathrm{O}$ of the released inorganic phosphate is not known.

In the soil-plant system it is important to distinguish between two types of phytases: 3-phytase and 6-phytase. The 3-phytases, EC 3.1.3.8, which are typical for microorganisms and most likely the prevalent phytase in the soil environment, first hydrolyze the ester bond at the 3-position of $\mathrm{IP}_{6}$ (myoinositol hexakisphosphate), which leads to the formation of $\mathrm{IP}_{5}$ (myo-inositol 1,2,4,5,6-pentakisphosphate) and free inorganic phosphate. In contrast, 6-phytases, EC 3.1.3.26, which are typical for plants, first hydrolyze the 6-position of $\mathrm{IP}_{6}$ forming $\mathrm{IP}_{5}$ (myo-inositol 1,2,3,4,5-pentakisphosphate) and free inorganic phosphate (Wodzinski and Ullah, 1996; Dvorakova et al., 1998) (Fig. 1). The aim of this study was to in-
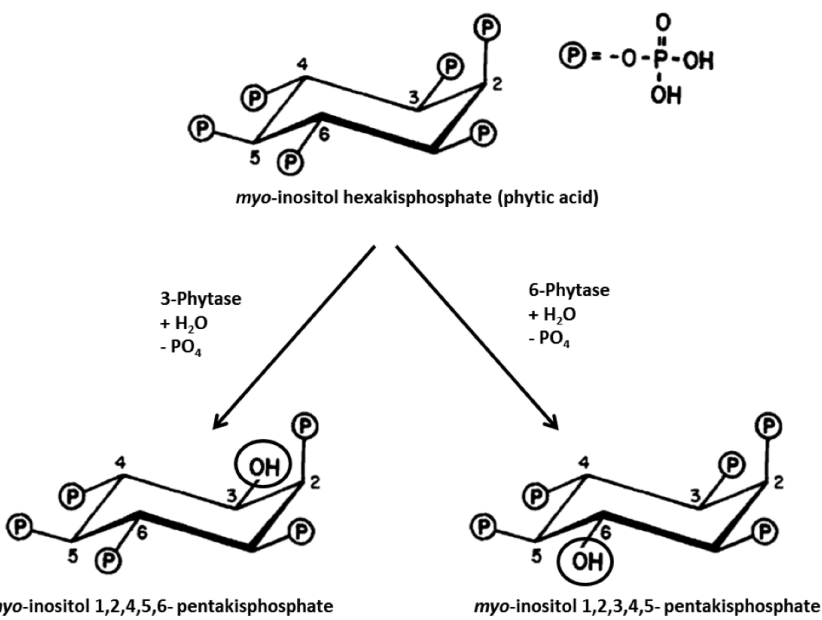

Figure 1. Phytic acid $\left(\mathrm{IP}_{6}\right)$ degradation to $\mathrm{IP}_{5}$ by 3-phytases and 6-phytases (modified from Dvořáková, 1998). 3-Phytases first hydrolyze the ester bond at the 3-position of $\mathrm{IP}_{6}$ (myo-Inositol hexakisphosphate), which leads to the formation of $\mathrm{IP}_{5}$ (myo-inositol 1,2,4,5,6-pentakisphosphate) and free inorganic phosphate. In contrast, 6-phytases first hydrolyze the 6-position, which leads to the formation of $\mathrm{IP}_{5}$ (myo-inositol 1,2,3,4,5-pentakisphosphate) and free inorganic phosphate. The numbering of the carbon atoms corresponds to the numbering for the $\mathrm{D}$ configuration.

vestigate the effect of a phytase from wheat, which belongs to the 6-phytases, and a phytase from Aspergillus niger, which belongs to the 3-phytases, on the $\delta^{18} \mathrm{O}$ values of released $\mathrm{P}_{\mathrm{i}}$.

\section{Material and methods}

\subsection{Preparation of enzymatic assays}

Enzymatic assays with phytases from two different organisms (phytase from wheat, Sigma Aldrich P1259, and phytase from Aspergillus niger, BASF, Natuphos ${ }^{\circledR}$, Natuphos 5000 ) were prepared to determine their effect on the oxygen isotope composition of released $\mathrm{P}_{\mathrm{i}}$. Assays consisted of $200 \mathrm{mM}$ acetate buffer (pH 5.5), with either $2 \mathrm{mM}$ phytic acid (Sigma Aldrich P8810), or $7 \mathrm{mM}$ glycerophosphate (Sigma Aldrich G6501) or $7 \mathrm{mM}$ adenosine 5'-monophosphate (Sigma Aldrich A1752) as a substrate and with $0.5 \mathrm{UN}$ of phytase ( $1 \mathrm{UN}$ is defined as the activity required to convert $1 \mu$ mol of substrate per minute).

Assays with acid phosphatases from potato and wheat germ consisted of $200 \mathrm{mM}$ acetate buffer (pH 4.8), $3 \mathrm{mM}$ phytic acid and $3 \mathrm{UN}$ of enzyme (Sigma Aldrich p3752 and Sigma Aldrich p3627). Proteins were further purified by dialysis with a dilution factor of 10000 , using a SnakeSkin dialysis tubing 10K MWCO $16 \mathrm{~mm}$ (Thermo Scientific, SnakeSkin, PI88243). All assay reagents were prepared in ${ }^{18} \mathrm{O}$ labeled and non-labeled double deionized water $\left(\mathrm{dd}-\mathrm{H}_{2} \mathrm{O}\right)$ and filter-sterilized. Batch assays had a volume of $3 \mathrm{~mL}$ and 
were prepared in $15 \mathrm{~mL}$ centrifuge tubes. Directly after the addition of the reagents, the tubes were closed and only opened for sampling. The concentration of released $P_{i}$ in the assays was monitored using the colorimetric malachite green method (Ohno and Zibilske, 1991). After $48 \mathrm{~h}, \mathrm{P}_{\mathrm{i}}$ yield was usually close to $65 \%$ and did not change any more, despite the enzyme being still active, which indicates that the original substrate $\mathrm{IP}_{6}$ molecule was degraded to myo-inositol biphosphate $\left(\mathrm{IP}_{2}\right)$ and four $\mathrm{P}_{\mathrm{i}}$ molecules $\left(4 \times \mathrm{P}_{\mathrm{i}} / 6 \times \mathrm{P}_{\mathrm{i}}=\right.$ $66.6 \%$ ). Enzymatic reactions were terminated after $72 \mathrm{~h}$ by adding $2 \mathrm{~mL}$ of $7 \mathrm{M}$ ammonia solution. Experiments were carried out in a temperature-controlled water bath at $37^{\circ} \mathrm{C}$. To test whether temperature had an effect on the isotopic fractionation, enzymatic assays were also prepared at $4{ }^{\circ} \mathrm{C}$. The $\delta^{18} \mathrm{O}$ of water in the assays was measured at the beginning and at the end of each experiment and did not vary over the course of the experiment. Released $\mathrm{P}_{\mathrm{i}}$ was purified according to the protocol of Tamburini et al. (2010). In brief, $P_{i}$ is first precipitated as magnesium ammonium phosphate (MAP), which can be retrieved by filtration and subsequently re-dissolved, purified and precipitated as silver phosphate $\left(\mathrm{Ag}_{3} \mathrm{PO}_{4}\right)$.

\subsection{Ultraviolet radiation (UVR) digestion}

The $\delta^{18} \mathrm{O}$ of $\mathrm{IP}_{6}$ and of the filtrate after the precipitation of MAP were analyzed after UVR digestion. $\mathrm{IP}_{6}$ and the filtrate were transferred in a solution with $20 \mathrm{~mL}$ of ${ }^{18} \mathrm{O}$ labeled and unlabeled dd- $\mathrm{H}_{2} \mathrm{O}$ and $3 \mathrm{~mL}$ of $28 \% \mathrm{H}_{2} \mathrm{O}_{2}$ and left overnight in a $25 \mathrm{~mL}$ quartz tube. The next day, the solutions were exposed to UVR (500 W mercury lamp) for $4 \mathrm{~h}$ at $27^{\circ} \mathrm{C}$. During the photodecomposition of organic $\mathrm{P}$ compounds, only $\mathrm{C}-\mathrm{O}$ bonds are cleaved, whereas $\mathrm{O}-\mathrm{P}$ bonds remain intact, leading to the release of the original $\mathrm{PO}_{4}$ moiety from the organic $\mathrm{P}$ compound without any incorporation of oxygen from water (Liang and Blake, 2006). UVR-released $\mathrm{P}_{\mathrm{i}}$ was then processed following the protocol of Tamburini et al. (2010). The $\delta^{18} \mathrm{O}$ of phosphate from the organic $\mathrm{P}$ compound $\left(\delta^{18} \mathrm{O}_{\mathrm{S}}\right)$ was calculated according to the modified equation from McLaughlin et al. (2006):

$\delta^{18} \mathrm{O}_{\mathrm{S}}=\frac{\left(\delta^{18} \mathrm{O}_{\mathrm{P}-\mathrm{UVR}}^{* * *} \times \delta^{18} \mathrm{O}_{\mathrm{W}}\right)-\left(\delta^{18} \mathrm{O}_{\mathrm{P}-\mathrm{UVR}} \times \delta^{18} \mathrm{O}_{\mathrm{W}}^{* * *}\right)}{\left(\delta^{18} \mathrm{O}_{\mathrm{P}-\mathrm{UVR}}^{* * *}-\delta^{18} \mathrm{OP}_{\mathrm{P}-\mathrm{UVR}}\right)-\left(\delta^{18} \mathrm{O}_{\mathrm{W}}^{* * *}-\delta^{18} \mathrm{O}_{\mathrm{W}}\right)}$,

with $\delta^{18} \mathrm{O}_{\mathrm{W}}^{* * *}$ and $\delta^{18} \mathrm{O}_{\mathrm{W}}$ being the $\delta^{18} \mathrm{O}$ of labeled and unlabeled water and $\delta^{18} \mathrm{OP}_{\mathrm{P}-U V R}$ being the $\delta^{18} \mathrm{O}$ of UVR-released phosphate in water which was labeled $\left(^{* * *}\right)$ or non-labeled. The fraction of oxygen which exchanged with water during UVR digestion $\left(F_{\text {exch }}\right)$ can be calculated according to

$F_{\mathrm{exch}}=\frac{\delta^{18} \mathrm{O}_{\mathrm{P}-\mathrm{UVR}}^{* * *}-\delta^{18} \mathrm{O}_{\mathrm{W}}^{* * *}}{\delta^{18} \mathrm{O}_{\mathrm{S}}-\delta^{18} \mathrm{O}_{\mathrm{W}}^{* * *}}$.

\subsection{Determination of $\delta^{18} \mathrm{O}$ values of phosphate and water}

Oxygen isotope analysis of $\mathrm{Ag}_{3} \mathrm{PO}_{4}$ was carried out with a vario PYRO Cube (Elementar, Hanau, Germany) connected in continuous flow to an Isoprime 100 isotope ratio mass spectrometer (Isoprime, Manchester, UK). The pyrolysis of $\mathrm{Ag}_{3} \mathrm{PO}_{4}$ took place at $1450{ }^{\circ} \mathrm{C}$ in a carbonbased reactor. A temperature-controlled purge and trap chromatography system was used to separate $\mathrm{CO}$ from $\mathrm{N}_{2}$. Results were calibrated against an internal $\mathrm{Ag}_{3} \mathrm{PO}_{4}$ standard (Acros Organics, Geel, Belgium; $\delta^{18} \mathrm{O}=14.2 \%$ Vienna Standard Mean Ocean Water (VSMOW)) and two benzoic acid standards distributed by the International Atomic Energy Agency (IAEA) (IAEA 601: $\delta^{18} \mathrm{O}=23.1 \%$; IAEA 602: $\delta^{18} \mathrm{O}=71.3 \%$ VSMOW). Analytical error calculated on replicate analysis of standards was better than $\pm 0.4 \%$.

For oxygen isotopes analysis of water, a $0.3 \% \mathrm{CO}_{2}$ and $\mathrm{He}$ mixture was equilibrated for $18 \mathrm{~h}$ at $25^{\circ} \mathrm{C}$ with the samples in airtight Exetainers. Aliquots of the $\mathrm{CO}_{2} / \mathrm{He}$ mixture from the headspace were sampled and transferred to a Delta V Plus mass spectrometer (Thermo Fisher Scientific Inc.) using a gas bench (GasBench II, Thermo Scientific Inc.). The oxygen isotope composition of water was derived from the isotope analysis of $\mathrm{CO}_{2}$. The system was calibrated with the international standards VSMOW, Standard Light Antarctic Precipitation (SLAP), and Greenland Ice Sheet Precipitation (GISP), distributed by the IAEA. Analytical error calculated on replicate analysis of standards was better than $\pm 0.06 \%$.

Oxygen isotope compositions are reported in the conventional delta notation $\left(\delta(\%)=\left(R_{\mathrm{X}} / R_{\mathrm{S}}-1\right) \times 1000\right.$, where $R$ denotes the ratio of the heavy to light isotope and $R_{\mathrm{X}}$ and $R_{\mathrm{S}}$ are the ratios of the sample and standard, respectively) with respect to VSMOW.

\subsection{Statistical analyses}

Standard deviations (SD), linear regressions, ANOVA and Tukey's HSD tests were calculated using the statistical software R. A one-way ANOVA was carried out for isotopic fractionations caused by different phytases and substrates. After rejecting the null hypothesis of the ANOVA, isotopic fractionations were compared with Tukey's HSD tests.

\section{Results}

\subsection{Incorporation of oxygen from water into $P_{i}$ during hydrolysis of $\mathrm{IP}_{6}$ by phytases}

Purified phytase from wheat and Aspergillus niger hydrolyzed approximately $65 \%$ of the phosphate molecules bound to $\mathrm{IP}_{6}$. Control experiments with crude protein extract from wheat phytase without any substrate revealed a substantial contamination of approximately $20 \mu \mathrm{mol} \mathrm{P}_{\mathrm{i}} \mathrm{UN}^{-1}$ protein extract. In order to remove this contamination, crude pro- 
Table 1. Results from UVR digestion of organic $\mathrm{P}$ compounds. The table shows measured $\delta^{18} \mathrm{O}$ values of ${ }^{18} \mathrm{O}-$ labeled water $\left(\delta^{18} \mathrm{O}_{\mathrm{W}}^{* * *}\right)$ and non-labeled $\left(\delta^{18} \mathrm{O}_{\mathrm{W}}\right)$ water, as well as $\delta^{18} \mathrm{O}$ values of UVR-released phosphate in assays with ${ }^{18} \mathrm{O}$-labeled water $\left(\delta^{18} \mathrm{O}_{\mathrm{IPx}}^{* * *}\right)$ and non-labeled water $\left(\delta^{18} \mathrm{O}_{\mathrm{IPx}}\right)$. The $\delta^{18} \mathrm{O}_{\mathrm{S}}$ value was calculated according to Eq. (1). Exchanged $F_{\text {exch }}$ is the fraction of oxygen atoms which exchanged with water calculated with Eq. (2).

\begin{tabular}{llllllll}
\hline Substrate & $\delta^{18} \mathrm{O}_{\mathrm{W}}$ & $\delta^{18} \mathrm{O}_{\mathrm{W}}^{* * *}$ & $\delta{ }^{18} \mathrm{O}_{\mathrm{P}-\mathrm{UVR}}$ & $\delta^{18} \mathrm{O}_{\mathrm{P} \text {-UVR }}^{* * *}$ & $F_{\text {exch }}$ & $\delta^{18} \mathrm{O}_{\mathrm{IPx}}$ & $\mathrm{SD}$ \\
\hline $\mathrm{IP}_{6}$ & -9.8 & 51.2 & 21.0 & 24.4 & 0.06 & 22.8 & 0.4 \\
$\mathrm{IP}_{2}$ (filtrate) & -10.4 & 73.3 & 21.7 & 22.4 & 0.01 & 22.0 & 0.4 \\
\hline
\end{tabular}

Table 2. $\delta^{18} \mathrm{O}$ values $\left(\%\right.$ ) of water $\left(\delta^{18} \mathrm{O}_{\mathrm{W}}\right)$, released phosphate $\left(\delta^{18} \mathrm{O}_{\mathrm{P}}\right)$ and phosphate in organic $\mathrm{P}$ compound $\left(\delta^{18} \mathrm{O}_{\mathrm{S}}\right)$ as well as isotopic fractionation $(\varepsilon)$, which was calculated according to Eqs. (6) and (7) with an assumed $\delta^{18} \mathrm{O}_{\mathrm{CON}}$ value of $15 \%$. Results are from experiments with $\mathrm{IP}_{6}$ as a substrate and with phytases from wheat and Aspergillus niger.

\begin{tabular}{llllllllll}
\hline Enzyme & Substrate & ${ }^{\circ} \mathrm{C}$ & $n$ & $\delta^{18} \mathrm{O}_{\mathrm{W}}$ & $\delta^{18} \mathrm{O}_{\mathrm{P}}$ & $\delta^{18} \mathrm{O}_{\mathrm{S}}$ & $\varepsilon$ & $\mathrm{Mean} \varepsilon$ & $\mathrm{SD}$ \\
\hline Phytase wheat (crude) & $\mathrm{IP}_{6}$ & 37 & 6 & -67 & 6.3 & 23.2 & $\mathrm{NA}$ & $\mathrm{NA}$ & $\mathrm{NA}$ \\
& $\mathrm{IP}_{6}$ & 37 & 3 & -10 & 18 & 23.2 & $\mathrm{NA}$ & & \\
& $\mathrm{IP}_{6}$ & 37 & 6 & 42.3 & 24.1 & 23.2 & $\mathrm{NA}$ & & \\
& $\mathrm{IP}_{6}$ & 37 & 6 & 94.2 & 33.9 & 23.2 & $\mathrm{NA}$ & & \\
& & & & & & & & & \\
Phytase wheat (dialyzed) & $\mathrm{IP}_{6}$ & 37 & 6 & -53.7 & 6.5 & 23.2 & 7.0 & 8.2 & 0.9 \\
& $\mathrm{IP}_{6}$ & 37 & 5 & -10.4 & 16.7 & 23.2 & 8.0 & & \\
& $\mathrm{IP}_{6}$ & 37 & 6 & 29.0 & 25.9 & 23.2 & 8.7 & & \\
& $\mathrm{IP}_{6}$ & 37 & 6 & 51.0 & 31.0 & 23.2 & 9.0 & & \\
& $\mathrm{IP}_{6}$ & 4 & 6 & -10.6 & 16.3 & 23.2 & 6.5 & 6.5 & 1.0 \\
& & & & & & & & & \\
Phytase A. niger (dialyzed) & $\mathrm{IP}_{6}$ & 37 & 2 & -75.4 & 1.4 & 23.2 & 9.2 & 7.7 & 1.0 \\
& $\mathrm{IP}_{6}$ & 37 & 3 & -10.4 & 16.5 & 23.2 & 7.1 & & \\
& $\mathrm{IP}_{6}$ & 37 & 3 & 48.4 & 30.6 & 23.2 & 6.9 & & \\
& $\mathrm{IP}_{6}$ & 37 & 3 & 77.2 & 37.7 & 23.2 & 7.8 & & \\
& $\mathrm{IP}_{6}$ & 4 & 3 & -10.6 & 17.1 & 23.2 & 9.5 & 9.5 & 0.9 \\
\hline
\end{tabular}

tein extracts were dialyzed. Mean $\delta^{18} \mathrm{O}$ values of released $\mathrm{P}_{\mathrm{i}}$ $\left(\delta^{18} \mathrm{O}_{\mathrm{P}}\right)$ from assays with both non-purified and purified proteins at different $\delta^{18} \mathrm{O}$ values of water $\left(\delta^{18} \mathrm{O}_{\mathrm{W}}\right)$ are shown in Fig. 2 and Table 2. Mean $\delta^{18} \mathrm{O}_{\mathrm{P}}$ values from assays with nonpurified wheat phytase ranged from 6.3 to $33.9 \%$, and linear regression of mean $\delta^{18} \mathrm{O}_{\mathrm{P}}$ values against mean $\delta^{18} \mathrm{O}_{\mathrm{W}}$ values resulted in a slope of 0.17 . Mean $\delta^{18} \mathrm{O}_{\mathrm{P}}$ values from assays with purified wheat phytase ranged from 6.5 to $31.0 \%$. Mean $\delta^{18} \mathrm{O}_{\mathrm{P}}$ values from assays with purified Aspergillus niger phytase ranged from 1.4 to $37.7 \%$ o. Linear regression of mean $\delta^{18} \mathrm{O}_{\mathrm{P}}$ values against mean $\delta^{18} \mathrm{O}_{\mathrm{W}}$ values from the assays with purified phytases resulted in a slope of 0.23 in the case of wheat phytase and in a slope of 0.24 in the case of Aspergillus niger phytase.

\subsection{Incorporation of oxygen from water into $P_{i}$ during UVR digestion}

The $\delta^{18} \mathrm{O}$ of $\mathrm{P}_{\mathrm{i}}$ produced during UVR digestion of $\mathrm{IP}_{6}$ in water with a $\delta^{18} \mathrm{O}$ of $-9.8 \%$ was 21.0 and $24.4 \%$ for water with a $\delta^{18} \mathrm{O}$ of $51.2 \%$, corresponding to an incorporation of $6 \%$ of oxygen from water into released $\mathrm{P}_{\mathrm{i}}$ (Table 1 ). The filtrate retrieved after precipitation of MAP contains $\mathrm{IP}_{2}$, which was also analyzed for its $\delta^{18} \mathrm{O}$. The $\delta^{18} \mathrm{O}$ of $\mathrm{P}_{\mathrm{i}}$ produced during UVR digestion of $\mathrm{IP}_{2}$ in water with a $\delta^{18} \mathrm{O}$ of $-10.4 \%$ o was 21.7 and $22.4 \%$ o for water with a $\delta^{18} \mathrm{O}$ of $73.3 \%$, corresponding to an incorporation of $1 \%$ of oxygen from water into the formed $\mathrm{P}_{\mathrm{i}}$ (Table 1). These findings confirm that the UVR-induced release of the original $\mathrm{PO}_{4}$ moiety from the organic P compound proceeded with little incorporation of oxygen from water.

\subsection{Oxygen isotope composition of $P_{i}$ released after hydrolysis of $\mathrm{AMP}$ and $\mathrm{GPO}_{4}$ by phytase and after hydrolysis of IP 6 by acid phosphatase}

Phytases can hydrolyze single phosphomonoester substrates, and some acid phosphatases can partly hydrolyze $\mathrm{IP}_{6}$ (Gibson and Ullah, 1988; Oh et al., 2004; Annaheim et al., 2013). For this reason, the effect of wheat phytase on adenosine $5^{\prime}$-monophosphate (AMP) and on glycerophosphate $\left(\mathrm{GPO}_{4}\right)$ used in a previous study (von Sperber et al., 2014) was tested. Wheat phytase hydrolyzed approximately $72 \%$ of AMP and approximately $80 \%$ of $\mathrm{GPO}_{4}$. Experiments with AMP as a substrate $\left(\delta^{18} \mathrm{O}_{\mathrm{S}}=15.8 \%\right.$ ), which were carried out in assays with a $\delta^{18} \mathrm{O}_{\mathrm{W}}$ of $-45.5 \%$, resulted in a mean $\delta^{18} \mathrm{O}_{\mathrm{P}}$ 

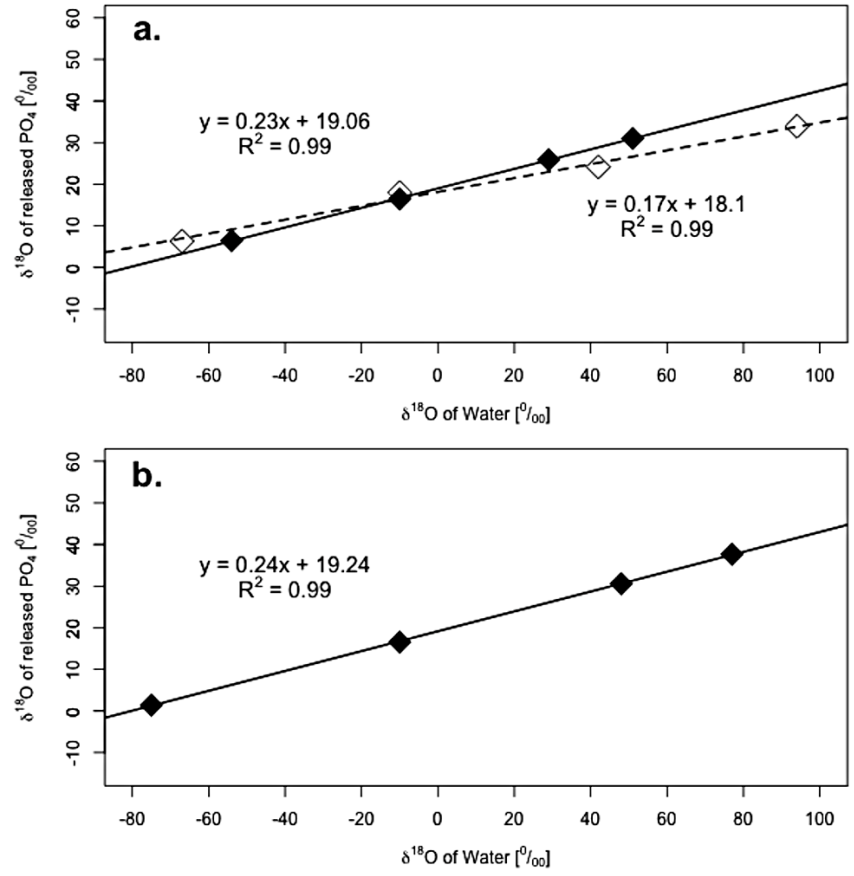

Figure 2. Mean $\delta^{18} \mathrm{O}$ values of released $\mathrm{P}_{\mathrm{i}}\left(\delta^{18} \mathrm{O}_{\mathrm{P}}\right)$ at different $\delta^{18} \mathrm{O}$ values of water $\left(\delta^{18} \mathrm{O}_{\mathrm{W}}\right)$ from (a) assays with non-purified wheat phytase (dashed line) and purified wheat phytase (solid line) (b) an assay with purified Aspergillus niger phytase.

of $-1.9 \%$. Experiments with $\mathrm{GPO}_{4}$ as a substrate $\left(\delta^{18} \mathrm{O}_{\mathrm{S}}=\right.$ $16.6 \%$ ), which were carried out in assays with a $\delta^{18} \mathrm{O}_{\mathrm{W}}$ of $-50.4 \%$, resulted in a mean $\delta^{18} \mathrm{O}_{\mathrm{P}}$ of $-2.4 \%$ (Table 3 ).

In addition, two acid phosphatases from potato and wheat germ with $\mathrm{IP}_{6}$ as a substrate were tested. Acid phosphatase from wheat germ hydrolyzed approximately $10 \%$ of $\mathrm{IP}_{6}$ and acid phosphatase of potato hydrolyzed approximately $40 \%$ of $\mathrm{IP}_{6}$. Experiments with acid phosphatase from wheat germ were carried out in assays with a $\delta^{18} \mathrm{O}_{\mathrm{W}}$ of $-58.5 \%$ and resulted in a mean $\delta^{18} \mathrm{O}_{\mathrm{P}}$ of $3.0 \%$. Experiments with acid phosphatase from potato were carried out in assays with a $\delta^{18} \mathrm{O}_{\mathrm{W}}$ of $-9.8 \%$ and resulted in a mean $\delta^{18} \mathrm{O}_{\mathrm{P}}$ of $16.7 \%$ (Table 3).

\section{Discussion}

\subsection{Implications of incorporation of oxygen from water into $P_{i}$ during hydrolysis of ${ } P_{6}$ by phytases}

The slopes from assays with purified phytases are close to 0.25 , similar to experiments conducted with phosphomonoesterases like alkaline and acid phosphatases (Liang and Blake, 2006; von Sperber et al., 2014). However, both slopes $(0.23$ and 0.24$)$ are significantly different from 0.25 (ANOVA, $p<0.05$ ). This indicates that the contamination with $P_{i}$ from the crude extract, where we observe a strong deviation in the slope, may not have been fully removed by our purification step.

The finding of a 0.25 slope implies that one oxygen atom from water is incorporated into each released $P_{i}$. From this observation follows that the enzymatic release of $\mathrm{P}_{i}$ from $\mathrm{IP}_{6}$ proceeds by cleaving the $\mathrm{P}-\mathrm{O}$ bond of the oxygen connected to myo-inositol via the addition of oxygen from water, a process that is different from the abiotic photodecomposition, where $\mathrm{C}-\mathrm{O}$ bonds are cleaved and $\mathrm{P}-\mathrm{O}$ bonds remain intact.

\subsection{Oxygen isotope fractionation during the incorporation of oxygen from water into $P_{i}$}

Assuming that released $\mathrm{P}_{\mathrm{i}}$ consists of three oxygen atoms from the original substrate and one oxygen which has been incorporated from water, the following mass balance can be applied to determine the oxygen isotope fractionation $(\varepsilon)$ caused by phytases (Liang and Blake, 2006):

$\delta^{18} \mathrm{O}_{\mathrm{P}}=0.75 \times \delta^{18} \mathrm{O}_{\mathrm{S}}+0.25 \times\left(\delta^{18} \mathrm{O}_{\mathrm{W}}+\varepsilon\right)$,

where $\delta^{18} \mathrm{O}_{\mathrm{P}}$ is the $\delta$ value of released $\mathrm{P}_{\mathrm{i}}, \delta^{18} \mathrm{O}_{\mathrm{S}}$ is the $\delta$ value of the substrate (meaning the average value of the 4phosphate released from $\mathrm{IP}_{6}$ ), $\delta{ }^{18} \mathrm{O}_{\mathrm{W}}$ is the $\delta$ value of the water and $\varepsilon$ is the isotopic fractionation.

The analysis of $\delta^{18} \mathrm{O}_{\mathrm{P}}$ and $\delta^{18} \mathrm{O}_{\mathrm{W}}$ is straightforward, but the determination of $\delta^{18} \mathrm{O}_{\mathrm{S}}$ is more complicated. Compared to single phosphomonoesters, such as glycerophosphate or adenosine $5^{\prime}$-monophosphate, phytic acid consists in total of six phosphate molecules, which all might have different $\delta^{18} \mathrm{O}$ values. The direct determination of the $\delta^{18} \mathrm{O}$ of each of the phosphate molecules attached to myo-inositol is not possible. However, the bulk isotope composition of the phosphate moieties from $\mathrm{IP}_{6}$ and $\mathrm{IP}_{2}$ can be determined, allowing for the calculation of $\delta^{18} \mathrm{O}_{\mathrm{S}}$. Our results indicate that the original substrate $\mathrm{IP}_{6}$ molecule was degraded to $\mathrm{IP}_{2}$ and $4 \mathrm{P}_{\mathrm{i}}$ molecules $\left(\mathrm{IP}_{6} \rightarrow \mathrm{IP}_{5}+\mathrm{P}_{\mathrm{i}} \rightarrow \mathrm{IP}_{4}+2 \mathrm{P}_{\mathrm{i}} \rightarrow \mathrm{IP}_{3}+3 \mathrm{P}_{\mathrm{i}} \rightarrow \mathrm{IP}_{2}+4 \mathrm{P}_{\mathrm{i}}\right) . \quad$ In this case, $\delta^{18} \mathrm{O}_{\mathrm{S}}$ corresponds to the $\delta^{18} \mathrm{O}$ of the $65 \%$ of phosphate molecules that were cleaved from $\mathrm{IP}_{6}$. By using a simple mass balance, $\delta^{18} \mathrm{O}_{\mathrm{S}}$ can be derived indirectly from $\delta^{18} \mathrm{O}$ of $\mathrm{IP}_{6}\left(\delta^{18} \mathrm{O}_{\mathrm{IP}_{6}}\right)$ and $\mathrm{IP}_{2}\left(\delta^{18} \mathrm{O}_{\mathrm{IP} 2}\right)$ as follows:

$\delta^{18} \mathrm{O}_{\mathrm{IP}_{6}}=2 / 3 \times \delta^{18} \mathrm{O}_{\mathrm{S}}+1 / 3 \times \delta^{18} \mathrm{O}_{\mathrm{IP} 2}$.

And solving for $\delta^{18} \mathrm{O}_{\mathrm{S}}$ :

$\delta^{18} \mathrm{O}_{\mathrm{S}}=3 / 2 \times \delta^{18} \mathrm{O}_{\mathrm{IP}_{6}}-1 / 2 \times \delta^{18} \mathrm{O}_{\mathrm{IP} 2}$.

The $\delta^{18} \mathrm{O}_{\mathrm{IP}_{2}}$ value was determined by oxidation photodigestion of the filtrate, which consists of $\mathrm{IP}_{2}$, after the MAP precipitation step. Digestion of the organic $\mathrm{P}$ compounds by UVR led to the release of $\mathrm{P}_{\mathrm{i}}$ with a $\delta^{18} \mathrm{O}_{\mathrm{IP}_{6}}$ value of $22.8 \%$ o $( \pm 0.4 \% \circ)$ and a $\delta^{18} \mathrm{O}_{\mathrm{IP} 2}$ value of $22.0 \%$ ( $( \pm 0.4 \% \circ)$ (Table 1$)$. Using these values in Eq. (5) we calculate a $\delta^{18} \mathrm{O}_{\mathrm{S}}$ value of $23.2 \% o\left( \pm 0.7 \%\right.$ ). Solving Eq. (3) with the obtained $\delta^{18} \mathrm{O}_{\mathrm{S}}$ 
Table 3. $\delta^{18} \mathrm{O}$ values of water $\left(\delta^{18} \mathrm{O}_{\mathrm{W}}\right)$, released phosphate $\left(\delta^{18} \mathrm{O}_{\mathrm{P}}\right)$ and phosphate in organic $\mathrm{P}$ compound $\left(\delta^{18} \mathrm{O}_{\mathrm{S}}\right)$ as well as isotopic fractionation $(\varepsilon)$, which was calculated according to Eqs. (6) and (7) with an assumed $\delta^{18} \mathrm{O}_{\mathrm{CON}}$ value of $15 \%$. Results are from experiments with $\mathrm{IP}_{6}, \mathrm{AMP}$ and $\mathrm{GPO}_{4}$ as substrates and with phytase from wheat and acid phosphatases from wheat germ and potato. ${ }^{*}$ Values from von Sperber et al. (2014).

\begin{tabular}{lllllllll}
\hline Enzyme & Substrate & ${ }^{\circ} \mathrm{C}$ & $n$ & $\delta^{18} \mathrm{O}_{\mathrm{W}}$ & $\delta^{18} \mathrm{O}_{\mathrm{P}}$ & $\delta^{18} \mathrm{O}_{\mathrm{S}}$ & $\varepsilon$ & $\mathrm{SD}$ \\
\hline Phytase wheat & $\mathrm{IP}_{6}$ & 37 & 5 & -10.4 & 16.7 & 23.2 & 7.7 & 1.2 \\
& $\mathrm{AMP}$ & 37 & 3 & -45.5 & -1.9 & 15.8 & -12.3 & 2.3 \\
& $\mathrm{GPO}_{4}$ & 37 & 3 & -50.4 & -2.4 & 16.6 & -12.0 & 2.2 \\
\multirow{5}{*}{ Apase wheat germ } & & & & & & & & \\
& $\mathrm{IP}_{6}$ & 37 & 3 & -58.5 & 3.0 & 23.2 & -0.9 & 0.6 \\
& $\mathrm{AMP}^{*}$ & 37 & 9 & -10.0 & 7.1 & 15.8 & -8.9 & 1.7 \\
Apase potato & $\mathrm{GPO}_{4}^{*}$ & 37 & 3 & -10.0 & 7.2 & 16.6 & -11.0 & 1.3 \\
& & & & & & & & \\
& $\mathrm{IP}_{6}$ & 37 & 2 & -9.8 & 16.7 & 23.2 & 7.2 & 2.9 \\
& $\mathrm{AMP}^{*}$ & 37 & 10 & -10.0 & 7.3 & 15.8 & -8.1 & 1.0 \\
& $\mathrm{GPO}_{4}^{*}$ & 37 & 6 & -10.0 & 7.0 & 16.6 & -11.8 & 1.3 \\
\hline
\end{tabular}

value results in an average $\varepsilon$ of $6.4 \%$ ( $\pm 2.9 \%$ ) in assays with wheat phytase and in an average $\varepsilon$ of $6.7 \%$ ( $( \pm 3.4 \%$ o $)$ in assays with Aspergillus niger phytase (Table 2). The isotopic fractionation is not significantly different between the two types of phytases (ANOVA; $p$ value $>0.05$ ).

We can refine our results by addressing the fact that the linear regression of $\delta^{18} \mathrm{O}_{\mathrm{P}}$ vs. $\delta^{18} \mathrm{O}_{\mathrm{W}}$ yields a slope of 0.23 in the case of wheat phytase and in a slope of 0.24 in the case of Aspergillus niger phytase (Fig. 2). These values are slightly below a slope of 0.25 , indicating small contaminations with $\mathrm{P}_{\mathrm{i}}$ that was not derived from $\mathrm{IP}_{6}$. These small contaminations are the reason for the linear relationship between $\delta^{18} \mathrm{O}_{\mathrm{W}}$ values and $\varepsilon$ (Table 2). In the case of wheat phytase, only $23 \%$ of oxygen in free inorganic phosphate in solution is derived from water. This means that free inorganic phosphate in solution, which has been released from the organic P substrate by enzymatic activity, only accounts for $92 \%$ of total inorganic phosphate in solution $(4 \times 23 \%)$. Therefore, $8 \%$ of free inorganic phosphate in solution is due to contamination. To account for this contamination, another term has to be included into the mass balance and Eq. 3 needs to be rewritten for experiments with wheat phytase as

$$
\begin{aligned}
& \delta^{18} \mathrm{O}_{\mathrm{P}}=0.92 \times\left(0.75 \times \delta^{18} \mathrm{O}_{\mathrm{S}}+0.25 \times \delta^{18} \mathrm{O}_{\mathrm{W}}+0.25 \times \varepsilon\right) \\
& +0.08 \times \delta^{18} \mathrm{O}_{\mathrm{CON}},
\end{aligned}
$$

and for experiments with Aspergillus niger phytase as

$$
\begin{aligned}
& \delta^{18} \mathrm{O}_{\mathrm{P}}=0.96 \times\left(0.75 \times \delta^{18} \mathrm{O}_{\mathrm{S}}+0.25 \times \delta^{18} \mathrm{O}_{\mathrm{W}}+0.25 \times \varepsilon\right) \\
& +0.04 \times \delta^{18} \mathrm{O}_{\mathrm{CON}},
\end{aligned}
$$

with $\delta^{18} \mathrm{O}_{\mathrm{CON}}$ being the $\delta^{18} \mathrm{O}$ of the contaminant. Analysis of $\delta^{18} \mathrm{O}_{\mathrm{CON}}$ was not possible; however, $\delta^{18} \mathrm{O}_{\mathrm{P}}$ values under environmental conditions usually lie within the range of $15 \%$ $( \pm 5) \%$ (Tamburini et al., 2014). Assuming a $\delta^{18} \mathrm{O}_{\mathrm{CON}}$ value of $15 \%$ results in an average $\varepsilon$ of $8.2 \% \circ( \pm 0.9 \%$ ) in assays with wheat phytase and in an average $\varepsilon$ of $7.7 \%$ o $( \pm 1.0 \%$ o $)$ in assays with Aspergillus niger phytase. Taking into account a possible contamination, $\varepsilon$ will change depending on the assumed $\delta^{18} \mathrm{O}_{\mathrm{CON}}$ value. An assumed $\delta^{18} \mathrm{O}_{\mathrm{CON}}$ value of $20 \%$ 。 would result in an $\varepsilon$ of $6.4 \% \circ( \pm 0.9 \% o)$ in the case of wheat phytase and in an $\varepsilon$ of $6.9 \% \circ( \pm 1.0 \% \circ)$ in the case of $A s$ pergillus niger phytase, while an assumed $\delta^{18} \mathrm{O}_{\mathrm{CON}}$ value of $10 \%$ would result in an $\varepsilon$ of $9.9 \% 0( \pm 0.9 \%$ ) in the case of wheat phytase and in an $\varepsilon$ of $8.6 \% \circ( \pm 1.0 \% 0)$ in the case of Aspergillus niger phytase.

These results provide an estimate of 6 to $10 \%$ for the oxygen isotopic fractionation during the release of $\mathrm{P}_{\mathrm{i}}$ from $\mathrm{IP}_{6}$, i.e., the oxygen incorporated is enriched in ${ }^{18} \mathrm{O}$ relative to the water it derived from. True inverse kinetic isotope fractionations are rare, and so far have not been observed for oxygen isotope effects in phosphorus cycling. It is unlikely that the apparent inverse isotope effect is caused by the contaminant, as $\delta^{18} \mathrm{O}_{\mathrm{CON}}$ would have to be $+65 \%$ in experiments with wheat phytase and $+117 \%$ in experiments with Aspergillus niger phytase to accommodate for a normal isotope effect (i.e., $\varepsilon<0 \% o$ ). These high $\delta$ values are not realistic, and we therefore assume that there is another reason for the observed positive isotopic fractionation.

An inverse kinetic isotope effect can be caused by a hidden equilibrium isotope fractionation. Unlike kinetic isotope fractionation, equilibrium isotope fractionation is often strongly temperature dependent. The effect of temperature on the isotopic fractionation caused by phytases was tested at 4 and $37^{\circ} \mathrm{C}$. In the case of wheat phytases, $\varepsilon$ had a value of $4.9 \% \circ( \pm 1.0 \% \circ)$, and in the case of Aspergillus niger phytase, $\varepsilon$ had a value of $8.0 \%$ ( $( \pm 0.9 \% \circ)$ at $4{ }^{\circ} \mathrm{C}$. The isotopic fractionation was not significantly different between the two temperatures (ANOVA; $p$ value $>0.05$ ), mirroring the findings with phosphomonoesterases (Liang and Blake, 2006, 2009; von Sperber et al., 2014). This indicates that a hidden 
equilibrium isotope fractionation may not be the cause of the observed apparent inverse isotope fractionation.

\subsection{Comparison of phytase to acid phosphatase oxygen isotope fractionation}

Phytases can vary significantly in their catalytic properties and mechanisms. For example, depending on the optimum $\mathrm{pH}$ of catalysis, they can be either alkaline, neutral or acid phosphatases (Mullaney and Ullah, 2003). Most plant and fungal phytases belong to the histidine acid phosphatases, which share the same amino acid sequence motif (RHGXRXP) at their active sites as acid phosphatases and nucleotidases (van Etten et al., 1991; Oh et al. 2004; Kostrewa et al., 1997, 1999; Lim et al., 2000). The amino acid sequence motif at the active site of phosphatases drives the reaction mechanisms, which can lead to either the incorporation of an oxygen atom derived from a water molecule into the newly formed phosphate (Lindqvist et al., 1994; Knöfel and Sträter, 2001; Ortlund et al., 2004), e.g., acid phosphatases or nucleotidases, or to the incorporation of an oxygen atom derived from a hydroxide ion, e.g., alkaline phosphatases (Kim and Wickoff, 1991; Stec et al., 2000). It has been suggested that these two types of reaction mechanisms are the reason why different phosphomonoesterases cause different isotopic fractionations (von Sperber et al., 2014). Based on these findings it can be expected that the isotopic fractionation caused by phytases is similar to that of acid phosphatases and nucleotidases.

The action of wheat phytase led to a $\varepsilon$ of $-12.3 \%$ o $( \pm 2.3 \% \circ)$ in the case of AMP and of $-12.0 \%$ ( $( \pm 2.2 \% \circ)$ in the case of $\mathrm{GPO}_{4}$ (calculated according to Eqs. 6 and 7 with a $\delta^{18} \mathrm{O}_{\mathrm{CON}}$ value of $15 \%$; Table 3 ). These fractionations are similar to those reported for acid phosphatases from wheat germ and potato (approximately $-10 \%$; von Sperber et al., 2014). Acid phosphatase from wheat germ hydrolyzed approximately $10 \%$ of $\mathrm{IP}_{6}$, while acid phosphatase of potato hydrolyzed approximately $40 \%$ of $\mathrm{IP}_{6}$. The $\delta^{18} \mathrm{O}$ of the myoinositol phosphate derivates of these reactions were not analyzed. Using a value of $23.2 \%$ of $\delta^{18} \mathrm{O}_{S}$, obtained from the phytase experiment, resulted in an $\varepsilon$ of $-0.9 \%$ ( \pm 0.6$)$ in the case of acid phosphatase from wheat germ and an $\varepsilon$ of $7.2 \%$ $( \pm 2.9)$ in the case of acid phosphatase from potato (Table 3$)$. The isotopic fractionation caused by potato acid phosphatase is similar to those caused by the two phytases used in this study. The isotopic fractionation caused by wheat germ acid phosphatase differs by approximately $8 \%$ compared to fractionation caused by phytases. The activity of wheat germ acid phosphatase with $\mathrm{IP}_{6}$ as a substrate was very low, indicating that this enzyme was only able to cleave one phosphate moiety from $\mathrm{IP}_{6}$. One possibility to explain this observation is that the $\delta^{18} \mathrm{O}_{\mathrm{S}}$ value of this single moiety of $\mathrm{IP}_{6}$ is lower than $23.2 \%$. The determination of the $\delta^{18} \mathrm{O}_{\mathrm{S}}$ values of the single phosphate molecules is a challenge beyond the scope of this study which needs to be addressed in future. The obser- vation of generally strong similarities in the oxygen isotope fractionation between phytases and acid phosphatases supports the hypothesis that the reaction mechanisms catalyzed by these enzymes are similar.

\subsection{Apparent substrate dependency of oxygen isotope fractionation}

The isotopic fractionation caused by phytases and acid phosphatases differ systematically with varying substrates, and encompass a range from inverse (relative enrichment in ${ }^{18} \mathrm{O}$, positive $\varepsilon$ ) to normal (relative depletion in ${ }^{18} \mathrm{O}$, negative $\varepsilon$ ) isotope effects. At first sight, this striking substratedependency of the isotopic fractionation implies a substratedependent mode of function of hydrolysis that may involve a multi-step process, with competing inverse and normal isotope effects. While such a scenario is not impossible, there may be a more straightforward explanation for this phenomenon. We hypothesize that there may be a difference in the $\delta^{18} \mathrm{O}$ of the bridging oxygen atom $(\mathrm{C}-\mathrm{O}-\mathrm{P})$ and the three non-bridging oxygen atoms $(\mathrm{O}-\mathrm{P})$ in organic phosphate compounds. If the enzymatic hydrolysis of phosphate esters leads to an isotope fractionation, it is by all means possible that the synthesis of phosphate esters by kinases also leads to an isotope fractionation. This is an important aspect which should be addressed in future studies looking at the effect of phosphatases on the oxygen isotope composition of phosphate. Therefore, if the $\mathrm{C}-\mathrm{O}-\mathrm{P}$ bridging oxygen atoms are depleted in ${ }^{18} \mathrm{O}$ relative to the non-bridging oxygen atoms, the $\delta^{18} \mathrm{O}$ of $\mathrm{P}_{\mathrm{i}}$ cleaved from $\mathrm{IP}_{6}$ and $\mathrm{IP}_{2}$ by abiotic photodecomposition would be lower than the actual $\delta^{18} \mathrm{O}$ of the three oxygen atoms cleaved from $\mathrm{IP}_{6}$ during enzymatic activity. This would result in an underestimate of $\delta^{18} \mathrm{O}_{\mathrm{S}}$ which in turn would lead to a biased calculation of $\varepsilon$-i.e., the true value of $\varepsilon$ could be smaller than $0 \%$ and thus be a normal isotope effect. We consider this issue to be a crucial aspect for the interpretation of the effect of phosphatases on the oxygen isotope composition of phosphate. We have not yet found a way to verify this hypothesis, which would be a highly interesting task for future research.

\subsection{Implications to studies of biogeochemical cycling of $P$ in the soil-plant system}

It has been shown that some plants grown under P-limited conditions can exude phytases (Li et al., 1997a, b; Richardson et al., 2001; Lung and Lim, 2006). The measurements of these enzymatic activities in soils are usually conducted under $\mathrm{pH}$-buffered and temperature-controlled conditions with artificial substrates, e.g., para-nitrophenyl phosphate - i.e., these measurements can only provide information on the potential enzymatic activity, and not on the actual activity. In the natural soil environment these conditions can vary substantially and rates of hydrolysis might be much lower. For example, in soils, phytic acid might undergo adsorp- 
tion and/or precipitation reactions, prohibiting the diffusion of an $\mathrm{IP}_{6}$ molecule into the active site of the enzyme (Anderson, 1980; McKercher and Anderson, 1989; Ognalaga et al., 1994). Similarly phytase can be rapidly sorbed onto soil particles (George et al., 2005). Moreover, the use of paranitrophenyl phosphate as a substrate cannot distinguish between extracellular acid phosphatase activity and phytase activity. The isotopic imprint caused by phosphatases might be used to distinguish between the actual enzymatic processes occurring in situ. The effects of phosphomonoesterases and phosphodiesterases on the oxygen isotope composition of phosphate could be traced in alkaline Mediterranean soils (Gross and Angert, 2015). The enzymatic release of phosphate from added organic compounds led, on the one hand, to an increase in available $P_{i}$ concentration and, on the other hand, to a decrease in $\delta^{18} \mathrm{O}$ values of available $\mathrm{P}_{\mathrm{i}}$ (Gross and Angert, 2015). This decrease in $\delta^{18} \mathrm{O}$ values was attributed to the negative isotopic fractionation caused by alkaline phosphatases (Liang and Blake, 2006). Another recent study conducted on a 6500-year soil coastal dune chronosequence found that $\delta^{18} \mathrm{O}$ values of available $\mathrm{P}_{\mathrm{i}}$ were in isotopic equilibrium with soil water at younger sites and below isotopic equilibrium at older sites, with higher organic $\mathrm{P}$ contents. The low $\delta^{18} \mathrm{O}$ values at the older sites indicated higher mineralization rates of labile organic $\mathrm{P}$ compounds, in particular DNA, by extracellular phosphatases (Roberts et al., 2015). The findings of our study are therefore of high value in future studies for the interpretation of $\delta^{18} \mathrm{O}$ values of available phosphate extracted from soils with high phytic acid contents.

\section{Conclusions}

The present study indicates that the isotopic fractionation caused by phytases from wheat and Aspergillus niger is similar compared to the fractionation reported for acid phosphatases from wheat germ and potato, and that there is no substantial difference between oxygen isotope fractionation by 6-phytases and 3-phytases. This observation is attributed to the similar reaction mechanisms of phytases and acid phosphatases. Temperature does not have an influence on the observed isotopic fractionations, which alleviates the interpretation of $\delta^{18} \mathrm{O}$ values of phosphate extracted from soils under natural conditions with large diurnal and seasonal temperature fluctuations. Furthermore, this study highlights the influence of the substrate on the calculated isotopic fractionation caused by phosphatases. Our results support the hypothesis that $\delta^{18} \mathrm{O}$ values of the bridging oxygen atom $(\mathrm{C}-\mathrm{O}-$ $\mathrm{P}$ ) and the non-bridging oxygen atoms $(\mathrm{O}-\mathrm{P})$ in phosphate molecules of organic $\mathrm{P}$ compounds are different. As the hydrolysis of different organic phosphorus substrates by different phosphatases can lead to very different isotopic signals, our findings highlight the potential of oxygen isotopes associated with phosphate as a tracer for enzymatic processes in the soil-plant system. Future research should focus on the substrate effect on $\delta^{18} \mathrm{O}$ values of phosphate during enzymatic hydrolysis. On the one hand, efforts should be directed to test whether the bridging oxygen atom $(\mathrm{C}-\mathrm{O}-\mathrm{P})$ has a different $\delta^{18} \mathrm{O}$ values compared to the non-bridging oxygen atoms (O-P). On the other hand, it is important to test in the field whether the hydrolysis of different organic phosphate esters leads to different $\delta^{18} \mathrm{O}$ values of resin extractable $\mathrm{P}_{\mathrm{i}}$.

Acknowledgements. The authors would like to thank ETH Zurich for funding (grant number: ETH-02_10-2). We would also like to thank S. Bishop, M. Jaggi, V. Pfahler, and L. Mauclaire Schönholzer for their help in the laboratory; S. Canonica for granting us access to the UVR reactor; C. Plassard for providing us with purified phytase; H. Kries, E. Bünemann, H. Gamper and A. Oberson for advice; and P. Vitousek for insightful comments on the manuscript.

Edited by: X. Wang

\section{References}

Anderson, G.: Assessing organic phosphorus in soils, in: The role of phosphorus in agriculture, Madison, USA, Amer. Soc. Agron., 411-432, 1980.

Angert, A., Weiner, T., Mazeh, S., Tamburini, F., Frossard, E., Bernasconi, S. M., and Sternberg, M.: Seasonal variability of soil phosphate stable oxygen isotopes in rainfall manipulation experiments, Geochim. Cosmochim. Acta, 75, 4216-4227, 2011.

Angert, A., Weiner, T., Mazeh, S., and Sternberg, M: Soil phosphate stable oxygen isotopes across rainfall and bedrock gradients, Environ. Sci. Technol., 46, 2156-2162, 2012.

Annaheim, K. E., Rufener, C. B., Frossard, E., and Bünemann, E. K.: Hydrolysis of organic phosphorus in soil water suspensions after addition of phosphatase enzymes, Biol. Fertil. Soil., 49, 1203-1213, 2013.

Blake, R. E., O’Neil, J. R., and Surkov, A. V.: Biogeochemical cycling of phosphorus: Insights from oxygen isotope effects of phosphoenzymes, Am. J. Sci., 305, 596-620, 2005.

Chang, S. J. and Blake, R. E.: Precise calibration of equilibrium oxygen isotope fractionations between dissolved phosphate and water from 3 to $37^{\circ} \mathrm{C}$, Geochim. Cosmochim. Acta, 150, 314329, 2015.

Cohn, M.: Mechanisms of cleavage of glucose-1-phosphate, J. Biol. Chem., 180, 771-781, 1949.

Cohn, M.: Phosphate-water exchange reaction catalyzed by inorganic pyrophosphatase of yeast, J. Biol. Chem., 230, 369-380, 1958.

Cosgrove, D. J. and Irving, G. C. J.: Inositol phosphates: their chemistry, biochemistry, and physiology, Elsevier Scientific Pub. Co., Distributors for the US and Canada, Elsevier/North-Holland, Amsterdam, New York,New York, 1980.

Dalal, R. C.: Soil organic phosphorus, Adv. Agron., 29, 83-117, 1977.

Doolette, A. L., Smernik, R. J., and Dougherty, W. J.: Rapid decomposition of phytate applied to a calcareous soil demonstrated by a solution 31P NMR study, Eur. J. Soil Sci., 61, 563-575, 2010. 
Dvořáková, J.: Phytase: Sources, preparation and exploitation, Folia Microbiol., 43, 323-338, 1998.

Ehlers, K., Bakken, L. R., Frostegård, A., Frossard, E., and Bünemann, E. K.: Phosphorus limitation in a Ferralsol: Impact on microbial activity and cell internal $\mathrm{P}$ pools, Soil Biol. Biochem., 42, 558-566, 2010.

George, T. S., Richardson, A. E., and Simpson, R. J.: Behaviour of plant-derived extracellular phytase upon addition to soil, Soil Biol. Biochem., 37, 977-988, 2005.

Gibson, D. M. and Ullah A., H. J.: Purification and characterization of phytase from cotyledons of germinating soybean seeds, Arch. Biochem. Biophys., 260, 503-513, 1988.

Gross, A. and Angert, A.: What processes control the oxygen isotopes of soil bio-available phosphate?, Geochim. Cosmochim. Acta, 159, 100-111, 2015.

Gross, A., Nishri, A., and Angert, A.: Use of phosphate oxygen isotopes for identifying atmospheric-P sources: A case study at Lake Kinneret, Environ. Sci. Technol., 47, 2721-2727, 2013.

Hayes, J. E., Richardson, A. E., and Simpson, R. J.: Phytase and acid phosphatase activities in extracts from roots of temperate pasture grass and legume seedlings, Functional Plant Biol., 26, 801-809, 1999.

Kim, E. E. and Wyckoff, H. W.: Reaction mechanism of alkaline phosphatase based on crystal structures: Two-metal ion catalysis, J. Mol. Biol., 218, 449-464, 1991.

Knöfel, T. and Sträter, N.: Mechanism of hydrolysis of phosphate esters by the dimetal center of $5^{\prime}$-nucleotidase based on crystal structures, J. Mol. Biol., 309, 239-254, 2001.

Kolodny, Y., Luz, B., and Navon, O.: Oxygen isotope variations in phosphate of biogenic apatites, I. Fish bone apatite-rechecking the rules of the game, Earth Planet. Sci. Lett., 64, 398-404, 1983a.

Kostrewa, D., Grüninger-Leitch, F., D’Arcy, A., Broger, C., Mitchell, D., and van Loon, A. P. G. M.: Crystal structure of phytase from Aspergillus ficuum at $2.5 \AA$ resolution, Nat. Struct. Biol., 4, 185-190, 1997.

Kostrewa, D., Wyss, M., D’Arcy, A., and van Loon, A. P. G.: Crystal structure of Aspergillus niger $\mathrm{pH} 2.5$ acid phosphatase at $2.4 \AA$ resolution, J. Mol. Biol., 288, 965-974, 1999.

Li, J., Hegeman, C. E., Hanlon, R. W., Lacy, G. H., Denbow, D. M., and Grabau, E. A.: Secretion of active recombinant phytase from soybean cell-suspension cultures, Plant Physiol., 114, 1103-1111, 1997.

Li, M., Osaki, M., Rao, I. M., and Tadano, T.: Secretion of phytase from the roots of several plant species under phosphorusdeficient conditions, Plant Soil, 195, 161-169, 1997.

Liang, Y. and Blake, R.E.: Oxygen isotope signature of Pi regeneration from organic compounds by phosphomonoesterases and photooxidation, Geochim. Cosmochim. Acta, 70, 3957-3969, 2006.

Liang, Y. and Blake, R. E.: Compound- and enzyme-specific phosphodiester hydrolysis mechanisms revealed by $\delta 180$ of dissolved inorganic phosphate: Implications for marine P cycling, Geochim. Cosmochim. Acta, 73, 3782-3794, 2009.

Lim, D., Golovan, S., Forsberg, C. W., and Jia, Z.: Crystal structures of Escherichia coli phytase and its complex with phytate, Nat. Struct. Mol. Biol., 7, 108-113, 2000..
Lindqvist, Y., Schneider, G., and Vihko, P.: Crystal structures of rat acid phosphatase complexed with the transition-state analogs vanadate and molybdate, Eur. J. Biochem., 221, 139-142, 1994.

Longinelli, A. and Nuti, S.: Revised phosphate-water isotopic temperature scale, Earth Planet. Sci. Lett., 19, 373-376, 1973.

Lott, J. N. A., Ockenden, I., Raboy, V., and Batten, G. D.: Phytic acid and phosphorus in crop seeds and fruits: a global estimate, Seed Sci. Res., 10, 11-33, 2000.

Lung, S.-C. and Lim, B. L.: Assimilation of phytate-phosphorus by the extracellular phytase activity of tobacco (Nicotiana tabacum) is affected by the availability of soluble phytate, Plant Soil, 279, 187-199, 2006.

McKercher, R. B. and Anderson, G.: Organic phosphate sorption by neutral and basic soils, Commun. Soil Sci. Plant Anal., 20, 723-732, 1989.

McLaughlin, K., Paytan, A., Kendall, C., and Silva, S.: Oxygen isotopes of phosphatic compounds - Application for marine particulate matter, sediments and soils, Mar. Chem., 98, 148-155, 2006c.

Mullaney, E. J. and Ullah, A. H. J.: The term phytase comprises several different classes of enzymes, Biochem. Biophys. Res. Commun., 312, 179-184, 2003.

Ognalaga, M., Frossard, E., and Thomas, F.: Glucose-1-phosphate and Myo-inositol Hexaphosphate Adsorption Mechanisms on Goethite, Soil Sci. Soc. Am. J., 58, 332-337, 1994.

Oh, B.-C., Choi, W.-C., Park, S., Kim, Y., and Oh, T.-K.: Biochemical properties and substrate specificities of alkaline and histidine acid phytases, Appl. Microbiol. Biotechnol., 63, 362-372, 2004.

Ohno, T. and Zibilske, L. M.: Determination of Low Concentrations of Phosphorus in Soil Extracts Using Malachite Green, Soil Sci. Soc. Am. J., 55, 892 pp., 1991.

O’Neil, J. R., Vennemann, T. W., and McKenzie, W. F.: Effects of speciation on equilibrium fractionations and rates of oxygen isotope exchange between $\left(\mathrm{PO}_{4}\right) \mathrm{aq}$ and $\mathrm{H}_{2} \mathrm{O}$, Geochim. Cosmochim. Acta, 67, 3135-3144, 2003.

Ortlund, E., LaCount, M. W., and Lebioda, L.: Crystal structures of human prostatic acid phosphatase in complex with a phosphate ion and $\alpha$-Benzylaminobenzylphosphonic acid update the mechanistic picture and offer new insights into inhibitor design, Biochemical, 42, 383-389, 2003.

Paytan, A., Kolodny, Y., Neori, A., and Luz, B.: Rapid biologically mediated oxygen isotope exchange between water and phosphate, Global Biogeochem. Cy., 16, 13-1-13-8, 2002.

Pfahler, V., Dürr-Auster, T., Tamburini, F., M. Bernasconi, S., and Frossard, E.: ${ }^{18} \mathrm{O}$ enrichment in phosphorus pools extracted from soybean leaves, New Phytol., 197, 186-193, 2013.

Raboy, V.: Accumulation and Storage of Phosphate and Minerals, in: Cellular and Molecular Biology of Plant Seed Development, edited by: Larkins, B. A. and Vasil, I. K., Advances in Cellular and Molecular Biology of Plants, Springer Netherlands, 441477, 1997.

Richardson, A. E., Hadobas, P. A., and Hayes, J. E.: Acid phosphomonoesterase and phytase activities of wheat (Triticum aestivum $L$.) roots and utilization of organic phosphorus substrates by seedlings grown in sterile culture, Plant Cell Environ., 23, 397-405, 2000.

Richardson, A. E., Hadobas, P. A., and Hayes, J. E.: Extracellular secretion of Aspergillus phytase from Arabidopsis roots enables 
plants to obtain phosphorus from phytate, Plant J., 25, 641-649, 2001.

Richardson, A. E., Lynch, J. P., Ryan, P. R., Delhaize, E., Smith, F. A., Smith, S. E., Harvey, P. R., Ryan, M. H., Veneklaas, E. J., Lambers, H., Oberson, A., Culvenor, R. A., and Simpson, R. J.: Plant and microbial strategies to improve the phosphorus efficiency of agriculture, Plant Soil, 349, 121-156, 2011.

Roberts, K., Defforey, D., Turner, B. L., Condron, L. M., Peek, S., Silva, S., Kendall, C., and Paytan, A.: Oxygen isotopes of phosphate and soil phosphorus cycling across a 6500 year chronosequence under lowland temperate rainforest, Geoderma, doi:10.1016/j.geoderma.2015.04.010, 2015.

Shears, S. B. and Turner, B. L.: Nomenclature and terminology of inositol phosphates: clarification and a glossary of terms, in: Inositol Phosphates: Linking Agriculture and the Environment, CAB International, Wallingford, UK, 1-6, 2007.

Stec, B., Holtz, K. M., and Kantrowitz, E. R.: A revised mechanism for the alkaline phosphatase reaction involving three metal ions, J. Mol. Biol., 299, 1303-1311, 2000.

Stout, L. M., Joshi, S. R., Kana, T. M., and Jaisi, D. P.: Microbial activities and phosphorus cycling: An application of oxygen isotope ratios in phosphate, Geochim. Cosmochim. Acta, 138, 101116, 2014.

Tamburini, F., Bernasconi, S. M., Angert, A., Weiner, T., and Frossard, E.: A method for the analysis of the $\delta^{18} \mathrm{O}$ of inorganic phosphate extracted from soils with $\mathrm{HCl}$, Eur. J. Soil Sci., 61, 1025-1032, 2010.

Tamburini, F., Pfahler, V., Bünemann, E. K., Guelland, K., Bernasconi, S. M., and Frossard, E.: Oxygen isotopes unravel the role of microorganisms in phosphate cycling in soils, Environ. Sci. Technol., 46, 5956-5962, 2012.
Turner, B. L.: Inositol phosphates in soil: amounts, forms and significance of the phosphorlyated inositol stereoisomers, in: Inositol Phosphates: Linking Agriculture and the Environment, $\mathrm{CAB}$ International, Wallingford, UK, 186-207, 2007.

Turner, B. L. and Haygarth, P. M.: Phosphorus forms and concentrations in leachate under four grassland soil types, Soil Sci. Soc. Am. J., 64, 1090-1099, 2000.

Turner, B. L., Papházy, M. J., Haygarth, P. M., and Mckelvie, I. D.: Inositol phosphates in the environment, Phil. Trans. R. Soc. Lond., 357, 449-469, 2002.

van Etten, R. L. V., Davidson, R., Stevis, P. E., MacArthur, H., and Moore, D. L.: Covalent structure, disulfide bonding, and identification of reactive surface and active site residues of human prostatic acid phosphatase, J. Biol. Chem., 266, 2313-2319, 1991.

von Sperber, C., Kries, H., Tamburini, F., Bernasconi, S. M., and Frossard, E.: The effect of phosphomonoesterases on the oxygen isotope composition of phosphate, Geochim. Cosmochim. Acta, 125, 519-527, 2014.

Wodzinski, R. J. and Ullah, A. H. J.: Phytase, in: Advances in Applied Microbiology, edited by: Neidleman, S. L. and Laskin, A I., Academic Press, 263-302, 1996.

Young, M. B., McLaughlin, K., Kendall, C., Stringfellow, W., Rollog, M., Elsbury, K., Donald, E., and Paytan, A.: Characterizing the oxygen isotopic composition of phosphate sources to aquatic ecosystems, Environ. Sci. Technol., 43, 5190-5196, 2009.

Zimmermann, P., Zardi, G., Lehmann, M., Zeder, C., Amrhein, N., Frossard, E., and Bucher, M.: Engineering the root-soil interface via targeted expression of a synthetic phytase gene in trichoblasts, Plant Biotech. J., 1, 353-360, 2003.

Zohar, I., Shaviv, A., Klass, T., Roberts, K., and Paytan, A.: Method for the analysis of oxygen isotopic composition of soil phosphate fractions, Environ. Sci. Technol., 44, 7583-7588, 2010a.

Zohar, I., Shaviv, A., Young, M., Kendall, C., Silva, S., and Paytan, A.: Phosphorus dynamics in soils irrigated with reclaimed waste water or fresh water - A study using oxygen isotopic composition of phosphate, Geoderma, 159, 109-121, 2010b. 